\title{
VALODA KĀ KONSTITUCIONĀLA VĒRTĪBA
}

\section{LANGUAGE AS A CONSTITUTIONAL VALUE}

\author{
Sanita Osipova, Dr. iur. \\ Latvijas Universitātes Juridiskās fakultātes \\ Tiesību teorijas un vēstures zinātņu katedras profesore
}

\section{Summary}

The author explores the link between the constitutional values and the existence of a national state, viewing the Latvian language as one of the constitutional values. The article first addresses the notion of "value" and highlights its social and constitutional meaning. It continues with analysing protection of the Latvian language as a value at the constitutional level, asking whether the constitutional ranking gives the Latvian language a genuine and comprehensive protection and promotes its further development in all areas of society's life. The author claims that even protection at the constitutional level does not safeguard the official language from the threats of globalization, which, in the first place, affects science, thereby indirectly also impacting the higher education.

Atslēgvārdi: konstitucionālā identitāte, valsts valoda, vērtỉba

Keywords: constitutional identity, state language, value

\section{Ievads}

Latvijas Universitātes 77. starptautiskās zinātniskās konferences plenārsēdē tiesību zinātnieki no dažādu tiesību nozaru perspektīvas analizēja Satversmē nostiprināto vērtību aizsardzību. Tas, kādā līmenī valstī tiek aizsargātas un koptas konstitucionālās vērtības, ir vitāli būtisks jautājums, jo nosaka valsts un sabiedrības turpmākās attīstības vīziju, cita starpā arī to, vai nācija pastāvēs nākotnē.

Šajā rakstā autore vēsturiski un sistēmiski analizē, kāda ir konstitucionālo vērtību korelācija ar nacionālas valsts pastāvēšanas būtību, skatot to saistībā ar latviešu valodu kā konstitucionālu vērtību. Tāpēc rakstā visupirms atklāts jēdziena "vērtība" saturs, tā sociālā un konstitucionālā nozīme, bet tālāk analizēta valsts valodas kā vērtības aizsardzība Satversmes līmenī, pievēršot uzmanību, vai konstitucionālais rangs latviešu valodai sniedz patiesu un vispusīgu aizsardzību, veicinot tās tālāku attīstību visās sabiedrības dzìves jomās.

\section{Vērtības, konstitucionālās vērtības un konstitucionālā identitāte}

Gadsimtu gaitā vērtības ir pētījuši daudzi zinātnieki: teologi, filozofi, juristi, politologi u. c. Taču pat tad, ja sabiedrībā nepastāv zinātne, kas apzināti definē vērtības, tās pastāv sabiedrības kultūrā kā cilvēku kopdzīves fundaments. Sabiedrības eksistences pamatu veido komunikācija un sadarbība. Šo sadarbības un pat 
visas kopādzīvošanas jēgu, augstāko mērḳi nosaka vērtības, proti, tas, ko mēs kā sabiedrība un katrs atseviškss indivīds gribam sasniegt, izveidot, pasargāt. Sadarbības pastāvēšana ilgtermiṇā ir iespējama tikai ar nosacījumu, ja pastāv normu struktūra, kas nosaka mūsu darbības piel̦aujamos model̦us, harmonizē sadarbību, padara to mērḳtiecīgu. Normas, tostarp tiesību normas, tiek veidotas, lai aizsargātu vērtības.

Postindustriālajā sabiedrībāi pēdējos gados vērtības tiek pastiprināti definētas un normativizētas. Postmodernā kultūra, dodot ikvienam izvēli brīvi izpausties un abstrahējoties no tradicionālām kolektīvām vērtībām, ir būtiski mainījusi cilvēku uzskatus un uzvedību, kā arī kultūru kopumā. Pati kultūra ir ne vairs monohroma, bet gan multikulturāla un piedāvā vērtību plurālismu. ${ }^{2}$ No vienas puses, indivīdam ir dota tāda brīvība, kāda vēsturiski vēl nav pieredzēta, - lemt par to, "kas es esmu un ko gribu ar sevi darīt", bet, no otras puses, ir atslābušas sabiedrību kā kolektīvu vienojošās solidaritātes saites, jo tiek pārskatīts daudzu tradicionālu vērtību saturs. Tas biedē konservatīvāko sabiedrības daļu.

Vērtības organizē cilvēkus sociālai dzivei, sniedzot priekšstatu par labo un l̦auno, patieso un aplamo, nozīmīgo un nesvarīgo, ko var upurēt un kā dēḷ vajag upurēties. Vērtības ir garīgas un materiālas reālijas, kas l̦auj cilvēkiem apmierināt viņu vajadzības, vēlmes, intereses un liek atturēties vai tieši otrādi - piepūlēties, lai tās sasniegtu, iegūtu un saglabātu. ${ }^{3}$ Talkots Pārsons (Talcott Parsons, 1902-1979) pamatoja, ka ikkatram sociālo attiecību dalībniekam ir sava individuāla vērtību sistēma. Pārsons to nosauca par orientācijas sistēmu, jo vērtību sistēma nosaka gan indivīda, gan grupas orientāciju apkārtējā pasaulē, motivējot izvēlēties atbilstošu uzvedību. Pamatojoties uz vērtībām, indivīds novērtē situāciju, izvērtējot konkrēta uzvedības modeḷa atbilstību morāles normu, tiesību normu prasībām vai citiem standartiem. Sabiedrības veidoto vērtību sistēmu T. Pārsons definēja kā kultūras sistēmu, kuras normu etaloni, regulējot sociālās attiecības, ir cieši savstarpēji saistīti. ${ }^{4}$

Mūsdienu valsts modelis - konstitucionāla pārstāvniecības demokrātija, kas sniedz indivīdam aizvien plašākas brīvības, - ir veidojies gadsimtiem, ja ne gadu tūkstošiem ilgi. Rietumu kultūras mantojumā formulētā izpratne par dabiskajām tiesībām, cilvēka vērtību un racionalitāti un sociāli atbildīgu sabiedrību vienkārši pieprasa izveidot valsts iekārtu, kurā valda tautvaldība un tiek garantētas cilvēka pamattiesības un brīvības. Šo uzskatu un vērtību sistēmas attīstības galarezultātu mēs varētu saukt par eiropeiskās konstitucionālās identitātes pamatu, kas balstās uz cilvēka cieṇu kā vērtību jeb, kā uzskata Jirgens Hābermāss (Jürgen Habermas, dz. 1929) korelāciju starp personas pašcieņu un valsts pilsoņa statusu demokrātijā. ${ }^{5}$ Arī tiesiskas valsts koncepts ir Eiropas kultūras attīstības rezultāts. ${ }^{6}$ Savukārt

1 Bell D. The Coming of Post-industrial Society: A Venture in Social Forecasting. Basic Books, 1976, p. 37.

2 Diez-Medrano J. Nationalism, Ethnic Conflict and Democratic Govarnance. In: Koenig M., De Guchteniere P. (eds.). Democracy and Human Rights in Multicultural Societies. Hampshire, Burlington: Ashgate, 2007, pp. 22-24.

3 Бачинин В.А. Энциклопедия философии и социологии права. Санкт-Петербург: Юридический центр Пресс, 2006, с. 1007.

4 Парсон Т. О структуре социального действия. Москва: Академический Проект, 2002, с. 417-418.

5 Hābermāss J. Par Eiropas konstitūciju. Rīga: Zinātne, 2013, 37. lpp.

6 Sk., piemēram: Sommermann K. P., Schaffarzik B. Handbuch der Geschichte der Verwaltungsgerichtsbarkeit in Deutschland und Europa. Berlin: Springer Verlag, 2018, S. 3-5. 
spriedze starp universālām pārnacionālām cilvēktiesībām un nacionālu valstu pilsoņu pamattiesībām ir normatìvais pamats starptautiskai dinamikai. ${ }^{7}$

Tiesību doktrīnā un judikatūrā pēdējās desmitgadēs ir parādījies jauns jēdziens, lai apzīmētu kādas nācijas tiesību pamatu: valsts konstitucionālā identitāte. Līdz šim konceptam Eiropas tiesiskā doma ir nonākusi pakāpeniski. Šarls Luijs Monteskjē (Charles Louis de Secondat Baron de la Brède et de Montesquieu, 1689-1755) definēja ideju par nācijas garu jeb mentalitāti, kas noteic ikvienas tautas dzìvi, tostarp valsts iekārtu un tiesības. ${ }^{8}$ Karls Frīdrihs fon Savinji (Friedrich Karl von Savigny, 1779-1861) ${ }^{9}$ 19. gadsimtā pētīja "tautā valdošo tiesību garu jeb izjūtu”, ${ }^{10}$ Hanss Kelzens (Hans Kelsen, 1881-1973) ${ }^{11}$ 20. gadsimtā rakstīja, ka valsts tiesiskā kārtība izriet no pamatnormas. ${ }^{12}$ Savukārt 20. un 21. gadsimta mijā juristi secina, ka to nosaka valsts konstitucionālā identitāte. ${ }^{13}$ Vienlaikus aizvien plašāk tiek runāts par "konstitucionālo patriotismu" kā pamatu nācijas konstitucionālajai identitātei. "Konstitucionālais patriotisms" apvieno nāciju uzticībā konstitūcijai kā kopīgu vērtību nesējai. ${ }^{14}$

Eiropas tiesību filozofijā var izsekot šo konceptu pēctecīgai attīstībai. Tie ir nevis savstarpēji izslēdzoši, bet gan papildinoši koncepti. Lai gan jēdziens "konstitucionālā identitāte" bagātināja latviešu tiesību filozofiju tikai 2012. gadā, tomēr tiesību doktrīna, kas virzìta uz nācijas patības jeb mentalitātes juridisku aizsardzību, Latvijā arī iepriekš ir attīstījusies kopsolī ar Eiropas jurisprudences virzību, ja neskaita pārrāvumu padomju okupācijas gados.

Pēdējā desmitgadē ir bijušas plašas diskusijas par to, kas ir Satversmes kodols jeb mūsu valsts galvenās konstitucionālās vērtības, uz kurām balstīts Latvijas valstiskums. ${ }^{15}$ Visplašāko rezonansi sabiedrībā guva Valsts prezidenta izveidotās Konstitucionālo tiesību komisijas 2012. gada 17. septembra atzinums "Par Latvijas valsts konstitucionālajiem pamatiem un neaizskaramo kodolu". ${ }^{16}$ Liela vērība šajā atzinumā bija pievērsta valsts konstitucionālajai identitātei, uzsverot, ka valstī pastāv konstitucionālās vērtības, kas ir konkrētās sabiedrības pamatvērtības, jo nosaka valsts patību jeb identitāti. Tieši ar šo atzinumu mūsu konstitucionālo tiesību doktrīnā ienāca jauns jēdziens - konstitucionālā identitāte - un tika uzsākta diskusija par konstitucionālām vērtībām. Komisijas atzinumā uzsvērts, ka nācijas konstitucionālo identitāti visupirms nosaka valsts valoda un kultūra, bet "plašā nozīmē, pie tās pieder jo sevišḳi pamatvērtības". ${ }^{17}$

\footnotetext{
7 Hābermāss J. 2013, 45. lpp.

${ }^{8}$ Montesquieu Ch. L. Vom Geist der Gesetze. Tübingen: H. Lauppsche Buchhandlung, 1951, Bd. I, S. XXIII-XXIV.

9 Hattenhauer H. Das Europäische Rechtsgeschichte. 2. Aufl. Heidelberg: C. F. Müller Verlag, 1994, S. 472.

10 Von Savigny Fr. C. Vom Beruf unserer Zeit für Gesetzgebung und Rechtswissenschaft. Buch: Thibaut und Savigny: ihre programmatische Schriften. Hrsg. H. Hattenhauer. München, BEC, 2002, S. 95.

11 Hattenhauer H. 1994, S. 684.

12 Kelsen H. Allgemeine Theorie der Normen. Wien: Manz, 1979, S. 18 f.

13 Plašāk sk.: Rode K. Verfassungsidentität und Ewigkeitsgarantie: Anmerkungen Zu Einem Mythos Der Deutschen Staatsrechtslehre. New York, Washington: Peter Lang, 2011.

14 Baer S. Rechtssoziologie. Eine Einführung in die interdisziplinäre Rechtsforschung. Baden-Baden: Nomos, 2015, S. 72.

15 Piemēram, diskusija: Latvijas valsts kodolu meklējot. Jurista Vārds, 07.02.2012., Nr. 6 (705). Pieejams: http://www.juristavards.lv/index.php?menu=DOC\&id=243627 [aplūkots 19.02.2019.].

${ }^{16}$ Konstitucionālo tiesību komisijas viedoklis "Par Latvijas valsts konstitucionālajiem pamatiem un neaizskaramo Satversmes kodolu”, 17.09.2012. Pieejams: http://www.president.lv/images/modules/items/ PDF/17092012_Viedoklis_2.pdf [aplūkots 10.02.2019.].

17 Ibid.
} 
Tātad katras valsts būtību veido konstitucionālas pamatvērtības. Šīs pamatvērtības pastāv tautas apziṇā un vieno tautu, bet to aizsardzībai, kā arī tiesiskās noteiktības labad tās tiek fiksētas konstitūcijā. Te varētu pievienot atziṇu, ka valsts simboli arī ir kolektīvas vērtības, kas vieno sabiedrību, piesaistot to valstij un paužot valstsgribu, un tāpēc arī pieder pie valsts konstitucionālās identitātes. Proti, karogs, himna un gerbonis materializē un iezīmē sociālo kopību. Attieksme pret valsts simboliem l̦auj spriest par personas attieksmi pret savu valsti un tautu, kas citādi lielākoties paliek sabiedrībai slēpta.

Lai gan postmodernajā kultūrā tiek runāts par vērtību relatīvismu, ko cita starpā nosaka multikulturālas sabiedrības izveidošanās un personas pamattiesību tālāka attīstība, taču joprojām pastāv vērtības, kuras par būtiskām tiek atzītas kolektīvi un nemainīgi. Savukārt vērtīborientācijas nesaskaṇas sabiedrībā veicina vērtību pārvērtēšanu un nostiprināšanos, jo liek katram diskusijas dalībniekam pārbaudīt un precizēt savas pozīcijas. ${ }^{18}$ Tomēr tieši konstitucionālās vērtības kā kolektīvi orientieri apvieno sabiedrību, padara iespējamu personu savstarpēju sapratni, paaudžu pēctecỉbu un līdz ar to nodrošina valsts pastāvēšanu laikā. ${ }^{19}$

Konstitucionālo identitāti, kas vieno nāciju apziņas līmen̄î, visupirms to juridiski nostiprinot, var aizsargāt likumdevējs, izvēršot pamatvērtību saturu konstitūcijā, konstitucionālajos likumos un arī likumos. Latvijā nav konstitucionālo likumu tradīcijas, lai gan atsevišķi šādi likumi mūsu tiesību sistēmā tikuši pieņemti. ${ }^{20}$ Mūsu likumdevējs tradicionāli konstitucionālo identitāti juridiski nostiprinājis tieši konstitūcijā. Tā tika darīts, izstrādājot Satversmi, ${ }^{21}$ un tā notiek arī mūsdienās. Pēdējie šādi konstitūcijas grozijjumi tika veikti 2014. gada jūnijā, Latvijas Republikas 1922. gada Satversmei pievienojot jaunu ievadu. ${ }^{22}$ Tā teksts ietver nozīmīgākos latviešu tautas vēstures krustpunktus, kā arī būtiskākās tautas tradīcijas un konstitucionālās vērtības. Tautas vēsture un tradīciju konstitucionālā nozīme iepriekš nebija iekḷauta Satversmē, taču ievadā minētās vērtības - "latviešu valoda kā vienīgā valsts valoda, brīvība, vienlīdzība, solidaritāte, taisnīgums, godīgums, darba tikums un gimene kā saliedētas sabiedrības pamats" ${ }^{23}$ - jau bija nostiprinātas Satversmes tekstā. Latviešu valoda kā valsts valoda tika noteikta Satversmes 4. pantā 1998. gadā. ${ }^{24} \mathrm{Li} d z$ tam 4. pantā bija noteikts tikai valsts karoga standarts. Savukārt tādas konstitucionālās vērtības kā vienlīdzību, brīvību, solidaritāti, ǵimeni līdz Satversmes ievada pieņemšanai cita starpā aizsargāja pamattiesību normas. Taču konstitucionālo vērtību ziṇā visietilpīgākā norma ir Satversmes

18 Sīle V., Sīlis V. Refleksija par vērtībām tagadnes kontekstā. Akadēmiskā Dzīve, 2017/2018, Nr. 54, 76. lpp.

19 Plašāk sk.: Osipova S. Tautas gars, pamatnorma un konstitucionālā identitāte. Grām.: Tiesību interpretācija un tiesību jaunrade - kā rast pareizo līdzsvaru. Latvijas Universitātes 71. zinātniskās konferences rakstu krājums. Rìga: LU Akadēmiskais apgāds, 2013, 303.-309. lpp.

${ }^{20}$ Latvijas Republikas konstitucionālais likums "Par Latvijas Republikas valstisko statusu": LV likums. Pieņemts 21.08.1991. Pieejams: https://likumi.lv/doc.php?id=69512 [aplūkots 18.02.2019.]; Latvijas Republikas konstitucionālais likums "Cilvēka un pilsoṇa tiesības un pienākumi”: LV likums. Pieņemts 10.10.1991. Pieejams: https://m.likumi.lv/doc.php?id=72346 [aplūkots 18.02.2019.].

${ }^{21}$ Pleps J. Latvijas valsts konstitucionālie pamati. Grām.: Latvieši un Latvija. III sēj. Atjaunotā Latvijas valsts. Zin. red. T. Jundzis, G. Zemītis. Rīga: Latvijas Zinātņu akadēmija, 2013, 119.-122. lpp.

22 Grozijums Latvijas Republikas Satversmē: LV likums. Pieņemts 19.06.2014. Pieejams: https://likumi.lv/ ta/id/267428-grozijums-latvijas-republikas-satversme [aplūkots 18.02.2019.].

${ }^{23}$ Latvijas Republikas Satversme. Rīga: Latvijas Republikas Saeima, 2017, 3. lpp.

${ }^{24}$ Grozijumi Latvijas Republikas Satversmē: LV likums. Pieṇemts 15.10.1998. Pieejams: https://likumi.lv/ ta/id/50292-grozijumi-latvijas-republikas-satversme [aplūkots 11.03.2019.]. 
1. pants, kurš nosaka: "Latvija ir neatkarīga demokrātiska republika."25 Mūsdienu demokrātiskai valstij jābūt arī tiesiskai valstij, citādi tiktu kavēta demokrātijas ìstenošana, ${ }^{26}$ savukārt demokrātiskas tiesiskas valsts galvenais mērḳis ir taisnīguma nodrošināšana. ${ }^{27}$

Otrs valsts orgāns, kurš primāri aizsargā valsts konstitucionālās vērtības, ir konstitucionālā tiesa. ${ }^{28}$ Konstitucionālā justīcija darbojas, lai aizsargātu ne tikai konstitūcijas tekstu, bet arī tajā ietverto konstitucionālo identitāti, konstitucionālās vērtības. ${ }^{29}$ Mēs aizvien biežāk runājam par iekšèjiem un ārējiem apdraudējumiem valsts suverenitātei un tās konstitucionālajai identitātei. Tāpēc valstiskuma sargāšanai konstitucionālās tiesas konstitucionālās justīcijas ietvaros ir uzṇēmušās veikt tā saukto identitātes kontroli, kā tā nodēvēta vācu konstitucionālajā doktrīnā. Šāda kontrole jau ir tik pašsaprotama, ka to māca tiesību zinātṇu studentiem, kuri apgūst konstitucionālo tiesību pamatus. ${ }^{30}$ Arī Satversmes tiesa savā judikatūrā ir vērtējusi apstrīdētā regulējuma vai pieteikuma iesniedzēja argumentu atbilstību Latvijas Republikas konstitucionālajai identitātei un analizējusi vērtības, kas liktas Latvijas Republikas pamatā. ${ }^{31}$

\section{Valsts valoda kā konstitucionāla vērtība un konstitucionālās identitātes raksturlielums}

Latvijas Republikas konstitucionālo identitāti raksturo nāciju vienojoši simboli, kas vienlaikus ir konstitucionālas vērtības. Visupirms jāmin latviešu valoda. Profesore Ina Druviete (dz. 1958) raksta: "Latviešu valoda arī 21. gadsimtā atspoguḷo tautas vēsturi, kultūru un valodu kontaktu aspektā: tā ir neatņemama tautas dvēseles jeb, mūsdienu terminolog̣ijā, nacionālās identitātes daḷa."32

Vārds jeb valoda, kurā materializējas doma, ir viens no atskaites punktiem ikvienas sabiedrības izveidei un pastāvēšanai. Valoda ir eksistenciāli svarīga ikvienai personai. ${ }^{33}$ Valoda pilnveido cilvēku no biologiskas būtnes par sociālu būtni, dodot iespēju sazināties ar citiem cilvēkiem un liekot pamatu domāšanai, veidojot cilvēka personību. Valodas apgūšana palīdz personai iekḷauties sabiedrībā. ${ }^{34}$

${ }^{25}$ Latvijas Republikas Satversme, I nodaļa.

${ }^{26}$ Grigore-Bāra E., Koval̦evska A., Liepa L., Levits E., Mits M., Rezevska D., Rozenvalds J., Sniedzīte G. Latvija ir neatkarīga demokrātiska republika. Grām.: Latvijas Republikas Satversmes komentāri. Ievads. I nodaḷa. Vispārējie noteikumi. Zin. vad. R. Balodis. Rīga: Latvijas Vēstnesis, 2014, 152. lpp.

27 Satversmes tiesas 11.04.2007. spriedums lietā Nr. 2006-28-01, 20.1. punkts.

${ }^{28}$ Cox A. The Court and the Constitution. Boston: Houghton Mifflin Company, 1987, p. 347.

29 Degenhart Ch. Staatsrecht I Staatsorganisationsrecht. Mit Bezügeb zum Europarecht. 33. Aufl. Heidelberg: C. F. Müller, 2017, S. 333-334.

${ }^{30}$ Ibid., S. 108.

31 Ir pieņemta virkne būtisku spriedumu, kas ietver ar konstitucionālo identitāti un vērtībām saistītas atziņas, piemēram: Satversmes tiesas 29.11.2007. spriedums lietā Nr. 2007-10-0102, 17. punkts, Satversmes tiesas 29.06.2018. spriedums lietā Nr. 2017-25-0120, 2. punkts, Satversmes tiesas 02.07.2015. spriedums lietā Nr. 2015-01-01, 15.1. punkts u. c.

32 Druviete I. Latviešu valoda pēc neatkarības atgūšanas: valodas situācija un valodas politika. Grām.: Latvieši un Latvija. III sēj. Atjaunotā Latvijas valsts. Zin. red. T. Jundzis, G. Zemītis. Rīga: Latvijas Zinātṇu akadēmija, 2013, 245. lpp.

${ }^{33}$ Schweizer R. J. Sprache als Kultur und Rechtgut. In: Sommermann K. P., Huster S., Schulte M., Ruffert M. et al. Kultur und Wissenschaft: Berichte und Diskussionen auf der Tagung der Vereinigung der Deutschen Staatsrechtslehrer in Frankfurt am Main vom 5. bis 8. Oktober 2005. Berlin: Walter de Gruyter, 2011, S. 381.

${ }^{34}$ Luhmann N. Rechtssoziologie. Bd. II. München: Rowohlt, 1972, S. 224. 
Personas valoda apkārtējiem sniedz plašas zināšanas par runātāju: l̦auj saprast personas saknes, proti, no kura reg̣iona tā nāk, izglìtības līmeni, varbūt pat nodarbošanos, gaumi, takta sajūtu un humora izjūtu. Runātāja valodas lietojums l̦auj sabiedrībai nošķirt "savējo", kurš runā dzimtajā valodā, no tā, kam šì valoda ir svešvaloda. ${ }^{35}$ Proti, valodā mēs komunicējot izsakām sevi, un mūsu valoda raksturo mūs. Niklass Lūmans (Niklas Luhmann, 1927-1998) ${ }^{36}$ rakstīja, ka "sabiedrība nav spējīga iziet ārpus tām robežām, kuras tiek nospraustas valodā”. ${ }^{37}$ Viennozīmīgi valoda ir būtisks sabiedrības raksturlielums, saliedētājs un vērtība, kas l̦auj nodrošināt sabiedrības ilgtspēju.

Savukārt valsts valoda līdz ar citām valodas sociālajām funkcijām veic arī specifiskus valstiski svarīgus uzdevumus, jo nodrošina valsts funkcionēšanu un komunikāciju starp personu un valsti. ${ }^{38}$ Proti, valsts valoda visupirms ir konstitūcijas, likumu, pārvaldes un justīcijas valoda. Vienlaikus valsts valoda nodrošina sabiedrības integrāciju, nodrošinot iespēju sabiedrības locekḷiem savstarpēji komunicēt visiem saprotamā valodā. ${ }^{39}$ Lai persona varētu pilnvērtīgi līdzdarboties sociālajos procesos, valsts pienākums ir veidot izglìtības sistēmu, kurā apmācība notiek valsts valodā. Ideologiski izglìtỉba raksturojama gan kā pamattiesības, gan kā instruments, kas ḷauj personai iekḷauties pilsoniskā sabiedrībā un īstenot savas pamattiesības. ${ }^{40}$ Veidojot izglītību valsts valodā, valsts gan sekmē pilsoniskās sabiedrības vienotību, gan nodrošina katras personas pamattiesību īstenošanas priekšnoteikumu.

Valsts valoda nav nošķirama no nācijas konstitucionālās identitātes, uzskata profesors Volfgangs Kāls (Wolfgang Kahl, dz. 1965). ${ }^{41}$ Lai gan valoda ir būtiska nacionālās un arī konstitucionālās identitātes sastāvdaḷa, tomēr noteiktu sociālu procesu dēl, kas noris postmodernā sabiedrībā, valsts valoda tiek apdraudēta kā lielās, tā mazās valstīs. Lielu nāciju varētu raksturot kolektīva pašpietiekamības un pašvērtības apziṇa, taču mazu nāciju bieži vieno bailes pazust, izšḳist lielajās nācijās, zaudējot savu valodu un tādējādi savu patību. "Mūsu misija (ir) izdzīvot kā tautai," Lietuvas Republikas simtgadi sagaidot, teica Biržu pilsētas mērs Valdemārs Vaḷūūns (Valdemaras Valkiūnas, dz. 1959). ${ }^{42}$ Šì atziṇa kodolīgi raksturo visu emocionālo spektru, kas valda nelielām nācijām piederīgu cilvēku domās un jūtās.

Tomēr mūsdienās var būt apdraudēta arī lielas nācijas valoda. To nosaka globalizācijas procesi. No vienas puses, pasaulē atkal ir sākusies "lielā tautu staigāšana", bet, no otras puses, komunikācijai tīmeklī nav robežu. Globalizācija nozīmē personu saziṇu bez robežām. Tas bagātina cilvēkus, taču vienlaikus ietekmē valodas lietojumu. Piemēram, apdraudējumu valodai varētu radìt liels skaits tādu valodas

35 Luhmann N. 1972, S. 92.

36 Raiser T. Das lebende Recht. Rechtssoziologie in Deutschland. Baden-Baden: Nomos Verlag, 1999, S. 139.

37 Луман Н. Общество как система. Москва: Логос, 2004, с. 45.

38 Lässig C. L. Deutsch als Gerichts- und Amtssprache. Berlin: Duncker \& Humblot, 1980, S. 11-15.

39 Kahl W. Sprache als Kultur- und Rechtsgut. In: Sommermann K. P., Huster S., Schulte M., Ruffert M. et al. Kultur und Wissenschaft: Berichte und Diskussionen auf der Tagung der Vereinigung der Deutschen Staatsrechtslehrer in Frankfurt am Main vom 5. bis 8. Oktober 2005. Berlin: Walter de Gruyter, 2011, S. 421.

${ }^{40}$ Jarinovska K. 112. Ikvienam ir tiesības uz izglītību. Valsts nodrošina iespēju bez maksas iegūt pamatizglītību un vidējo izglītību. Pamatizglìtỉba ir obligāta. Grām.: Latvijas Republikas Satversmes komentāri. Ievads. I nodaḷa. Vispārējie noteikumi. Zin. vad. R. Balodis. Rīga: Latvijas Vēstnesis, 2014, 636. lpp.

41 Kahl W. 2011, S. 393.

42 Līcītis E. Saruna ar Biržu mēru Valdemāru Vaḷkūnu Lietuvas 100 gadu jubilejā. Latvijas Avīze, 16.02.2018., Nr. 34 [5973], 4. lpp. 
lietotāju, kuriem tā nav dzimtā valoda. Angḷu valoda ir dzimtā valoda 400 miljoniem runātāju, savukārt 1,4 miljardiem cilvēku tā ir pirmā svešvaloda. ${ }^{43} \mathrm{Kad}$ savā starpā sazinās runātāji, kuriem angḷ valoda ir svešvaloda un kuru valodas zināšanas nav pietiekamas, lai sazinātos korektā valodā, tas var novest pie atkāpšanās no gramatikas likumiem un atteikšanās no valodas bagātā vārdu krājuma, vārdu lietošanas pārnestā nozīmē utt. Tas iezīmē zināmu valodas vulgarizāciju. ${ }^{44}$ Proti, tas, ka valodu lieto milzumdaudz personu, kuras šo valodu īsti nepārvalda, var valodas plašo plūdumu sašaurināt līdz skopam minimumam, kas tiek lietots gramatiski nepareizās formās. Šāds, piemēram, ir british english apdraudējums globalizācijas procesos, kad, angliski sazinoties sveštautiešiem, tiek lietota visai primitiva angl̦u valoda ar salīdzinoši nelielu vārdu krājumu. ${ }^{45}$ Lìdzīgi iet arī vācu valodai. Daudziem Vācijas iedzīvotājiem vācu valoda nav ne dzimtā valoda, ne valoda, kurā mājās runā gimene. Tāpēc austriešu un vācu prese pauž bažas par vācu valodas nākotni, jo skolā bieži vien klasē vienīgais cilvēks, kas runā pareizā vācu valodā, ir skolotāja. ${ }^{46}$ Tomēr ikviena valoda ir pakḷauta dabiskām nenovēršamām izmaiņām. Valoda dzīvo līdz ar nāciju. Mainās sabiedrība, un tai līdzi mainās arī valodas lietojums. ${ }^{47}$

Lielu nāciju varētu satraukt zināms tās valodas pienācīga lietojuma apdraudējums, turpretī maza nācija baidās zaudēt savu valodu. Savukārt zaudēt valodu nācijai nozīmētu zaudēt arī būtisku dal̦u no kultūras mantojuma. Ikvienā kultūrā būtiska tās daḷa ir piesaistīta verbālai formai: folklora, literatūra, kinofilmas, dziesmu lirika. Tostarp arī visa jurisprudence, proti, tiesību normas, judikatūra un doktrīna, tiek formulēta verbāli. ${ }^{48}$

Latviešu nācija ir maza, to runātāju skaits, kuriem latviešu valoda ir dzimtā valoda, sasniedz aptuveni 1,5 miljonus. ${ }^{49}$ Vēsturiski ilgu laiku mēs esam bijusi tauta, kas pakḷauta citu tautu kundzībai, un tas ir ietekmējis arī valodas attīstību un lietojumu. No 13. gadsimta līdz pat 19. gadsimta beigām lielākajā daḷā Latvijas teritorijas valsts valoda bija vācu, bet 19. gadsimta beigās, kad Krievijas impērijā tika uzsākti valsts centralizācijas un rusifikācijas procesi, par valsts valodu kḷuva krievu valoda. ${ }^{50}$ Rusifikācijas politika Baltijā skāra visas sabiedrības dzìves jomas - gan valsts pārvaldi, gan kultūras dzīvi, gan izglìtību, ${ }^{51}$ apdraudot latviešu valodas turpmāku pastāvēšanu. ${ }^{52}$ 1918. gadā tika dibināta Latvijas valsts,

${ }^{43}$ Millward C. M., Hayes M. A Biography of the English Language. Cengage Learning, 2011, pp. 341-345.

${ }^{44}$ Piemēram, viduslaiku tautu kopējā valoda bija latinnu valoda, bet liela daḷa mazizglìtoto tās lietotāju un visai bieži arī izglītotas personas runāja vulgārā latīṇu valodā. Richter M. Studies in Medieval Language and Culture. Dublin: Four Courts Press, 1995, pp. 44-46.

45 Interesants pētījums par angḷu valodas likteni globalizētā pasaulē: Hackert S. The Emergence of the English Native Speaker: A Chapter in Nineteenth-Century Linguistic Thought. Boston, Berlin: Walter de Gruyter, 2012, pp. 241-270.

${ }^{46}$ Arp S., Elger K. Wo Deutsch eine Fremdsprache ist. In: Spiegel online. Pieejams: http://www.spiegel. de/spiegel/integration-an-manchen-schulen-bleiben-migrantenkinder-fast-unter-sich-a-1200736. html [aplūkots 11.03.2019.], sk. arī: So viele Schüler sprechen in ihrem Alltag nicht Deutsch. In: News. Pieejams: https://www.news.at/a/schule-deutsch-alltag-10322825 [aplūkots 11.03.2019.].

47 Millward C. M., Hayes M. 2011, pp. 8-16.

${ }^{48}$ Kahl W. 2011, S. 421

${ }^{49}$ Latviešu valoda ir Latvijas Republikas valsts valoda. Latviešu valodas aǵgentūra. Pieejams: https:// valoda.lv/valsts-valoda/ [aplūkots 11.03.2019.].

${ }^{50}$ Plašāk sk.: Osipova S. Latviešu juridiskās valodas attīstība pēc Pirmā pasaules kara. Grām.: Latvijas Universitātes žurnāls Juridiskā zinātne. 1. sēj. Rīga: Latvijas Universitāte, 2010, 81.-100. 1pp.

51 Thaden E. C. Russification in the Baltic Provinces and Finland, 1855-1914. Princeton, New Jersey: Princeton University Press, 2014, pp. 33-75.

${ }^{52}$ Rakstā nav izvērsts, kā Krievijas impērijā tika ierobežotas minoritāšu tiesības, taču tikai viens piemērs: skolās mācības notika krievu valodā, un minoritāšu bērni nedrīkstēja savā starpā sarunāties dzimtajā 
latvieši kḷuva par valstsnāciju, bet latviešu valoda - par valsts valodu. Jau valsti dibinot, bija skaidrs, ka latviešu valoda kḷūs par pilnvērtīgu nācijas valodu tikai tad, ja latviski būs iespēja sazināties visās sabiedrisko attiecību jomās: politikā, zinātnē, kultūrā, sadzīvē utt. Ja valoda nespēj nodrošināt kaut vienu no sabiedrisko attiecību jomām ar pietiekamu vārdu krājumu, tad komunikācijai nākas izmantot citas valodas jēdzienus vai pilnībā pāriet uz komunikāciju citā valodā. Tas ir būtisks apdraudējums ikvienai valodai. Laikā, kad citu nāciju valodas tika plaši lietotas valsts iestādēs un izglītībā, latviešu valoda no ši sabiedrisko attiecību lauka bija izslēgta. Latviešu valodai bija îsā laikā būtiski jāpapildina vārdu krājums ar jauniem jēdzieniem, cita starpā zinātnē un politikā. Tāpēc viens no jaunās valsts uzdevumiem bija dibināt nacionālu augstskolu, kas attīstītu latviešu valodu visās zinātṇu nozarēs un sagatavotu jaunos speciālistus, kuri savus amata pienākumus varētu veikt latviešu valodā. Latvijas Tautas padomes 3. sesijas 2. sēdē 1919. gada 15. jūlijā pēc tam, kad Latvijas Pagaidu valdības vadìtājs Kārlis Ulmanis (1877-1942) lìdz ar daudziem citiem nekavējoties risināmiem jautājumiem bija minējis: "Jāķeras pie darba Latvijas Universitātes atvēršanai: vēl šinī rudenī mēs ceram to veikt," 53 tika nobalsots par nacionālas augstskolas dibināšanu. Šim lēmumam sekoja Latvijas Pagaidu valdības rīkojums "Par Rīgas Politehniskā institūta pārn,emšanu", lai uz tā bāzes dibinātu nacionālo augstskolu. ${ }^{54}$

Tomēr arī pēc valsts dibināšanas līdzās latviešu valodai valsts orgānos un iestādēs turpināja lietot bijušās valsts valodas - vācu un krievu. ${ }^{55}$ Jau 1932. gadā, lai sekmētu latviešu valodas lietošanu valsts pārvaldē, tika izdoti Noteikumi par valsts valodu, kuri regulēja: "Valsts valodas lietošana obligātoriska armijā, flotē un visās pārējās valsts un pašvaldības iestādēs un uzṇēmumos, kā arī atsevišķu pilsoṇu un juridisko personu satiksmē ar tām." ${ }^{6}$ Taču, vērtējot situāciju valstī un respektējot minoritāšu tiesības, sekoja atrunas:

“2. piezīme. Pašvaldību orgānu sēdēs līdz 1935. gada pārvēlēšanām, ar priekšsēdētāja atḷauju, vai vismaz ar attiecīgā orgāna 1/3 locekḷu pieprasijumu, var lietot arī vācu un krievu valodu, bet uz viena sēdes dalībnieka pieprasījumu šinīs valodās turētās runas tulkojamas latviski.

3. Pilsētu un pagastu pašvaldībām, kurās pēc pēdējās tautas skaitīšanas datiem, vienas atsevišķas mazākuma tautības piederīgo nav mazāk par 50 procentiem, pašvaldības attiecībās ar šìs tautības piederīgiem pielaižama arī vācu vai krievu valodas lietošana. Minēto pašvaldību iestāžu sēdēs vācu vai krievu valodā turētās runas un iesniegumi uz viena sēdes dalïbnieka pieprasījumu jātulko latviski."57

Tikai 1934. gadā pēc autoritārā vadoṇa Kārḷa Ulmaṇa nākšanas pie varas latviešu valoda kluva par vienīgo valodu, kurā notiek saziṇa valsts iestādēs. Uzrunājot tautu Rankā, Madonā un Madlienā, 1934. gada 16. un 17. jūnijā K. Ulmanis teica: "[..] kas ir pirmā valoda Latvijā, - proti, šì pirmā valoda ir latviešu valoda! Mums nācās piedzìvot ... ka dažās pašvaldỉbas iestādēs jaunieceltie valdes locekḷi

valodā. Interesenti var plašāk lasīt, piemēram, atmiṇu grāmatā: Fēgezaks Z. fon. Baltiešu gredzens. Rìga: Vesta LK, 2019.

${ }^{53}$ Latvijas Tautas Padomes sēdes stenogrammas. Rīga: Satversmes sapulces izdevums, 1920, 108. lpp.

${ }^{54}$ Latvijas Pagaidu valdības rīkojums "Par Rīgas Politehniskā institūta pārṇemšanu”. Valdības Vēstnesis, 1919, Nr. 3, 3. lpp.

55 Plašāk sk.: Osipova S. 2010, 81.-100. lpp.

56 Noteikumi par valsts valodu: Ministru kabineta noteikumi. Pieṇemts 18.02.1932. Likumu un Ministru kabineta noteikumu krājums, 1932, Nr. 4, 55. lpp.

57 Ibid. 
nevar saprasties ar saviem darbiniekiem, jo tie nemāk latviski. Tik daudz taču mēs varam prasīt, lai tur būtu palīgi un darbinieki, kas prot latviski." ${ }^{5} 1935$. gadā tika pieņemts Likums par valsts valodu. ${ }^{59}$ Tikai dažus gadus vēlāk, 1940. gadā, padomju okupācija nāca līdz ar jaunu rusifikācijas vilni. ${ }^{60}$ Turēšanās pie savas valodas latviešiem nozīmēja palikšanu latvietībā par spìti tam, ka padomju vara bija izveidojusi “tautu sakausēšanas katlu”, kurā visām padomju tautām bija jāsakūst vienotā padomju tautā, kas runā krievu valodā. Latviešu vēsturiskajai pieredzei valodas jomā bija nozīme, 1990. gadā veidojot atjaunotās Latvijas Republikas valodu politiku un sevišksi rūpīgi aizsargājot latviešu valodu kā valsts valodu. ${ }^{61}$

Simptomātiski, ka aptuveni vienā laikā 20. gadsimta beigās gan jaunās valstis, gan valstis ar ievērojamu pieredzi nostiprināja valsts valodas statusu savās konstitūcijās. Nacionālie likumdevēji apzināja un aizsargāja konstitucionālo identitāti. Baltijas valstīm ir diezgan savstarpēji salīdzināmi risinājumi. Igaunijas 1992. gada 28. jūnija konstitūcijas sadaḷā par valsts pamatiem 6. pantā ir noteikts: "Igauṇu valoda ir valsts valoda." ${ }^{2}$ Lietuvas 1992. gada 25 . oktobra konstitūcijas 1. daḷs 14. pants pasludina lietuviešu valodu par valsts valodu. ${ }^{63}$ Latvija pēdējā no Baltijas valstīm valsts valodu iestrādāja 1922. gada Satversmē, 1998. gada 15. oktobrī Satversmes 4. pantu papildinot ar pirmo teikumu: "Valsts valoda Latvijas Republikā ir latviešu valoda."64 Baltijas valstis, kurām valsts valoda ir īpaši nozìmīgs jautājums, nebūt nav ne pirmās, ne vienīgās, kas savās konstitūcijās nostiprināja valsts valodu kā vienu no pamatvērtībām. Arī Francija savā 1958. gada konstitūcijā gandrīz simultāni ar Baltijas valstīm 1992. gada 25. jūnijā veica papildinājumus. Konstitūcijas I daḷas "Par suverenitāti" 2. pants tika papildināts ar pirmo punktu "Franču valoda ir Republikas valoda", atstājot aiz valodas kā nācijas suverenitātes pamata valsts karogu, himnu, republikas devīzi un principus. ${ }^{65}$ Globālajā, multikulturālajā pasaulē, lai aizsargātu savu konstitucionālo identitāti, valstis apzinās valsts valodas nozīmi un nepieciešamību to papildus juridiski aizsargāt.

\section{Latviešu valoda zinātnē un izglîtībā: kopsakars un apdraudējumi}

Latvijas likumdevējs valsts valodu konstitucionāli ir aizsargājis divkārt: 1998. gada 15. oktobrī papildinot 1. nodal̦as 4. pantu ar pirmo teikumu, kā arī 2014. gada jūnijā, pievienojot Satversmei jaunu ievadu, kurā noteikta "latviešu valoda kā vienīgā valsts valoda". ${ }^{6}$ Tā bija likumdevēja atbilde uz tā saucamo valodas referendumu jeb 2012. gada tautas nobalsošanu par likumprojektu "Grozijumi

\footnotetext{
${ }^{58}$ Ulmanis K. Runa tautas sapulcēs Rankā, Madonā un Madlienā 16. un 17. jūnijā. Valdības Vēstnesis, 1934, Nr. 135, 1. lpp.

${ }^{59}$ Likums par valsts valodu: LV likums. Pieṇemts 05.01.1935. Valdības Vēstnesis, 1935, Nr. 7, 1. lpp.

${ }^{60}$ Pelkaus E. Okupācijas varu politika Latvijā 1939-1991: dokumentu krājums. Latvijas Valsts arhīvs. Riga: Nordik, 1999, 347.-348. lpp.

${ }^{61}$ Druviete I. 2013, 258. lpp.

62 The Constitution of the Republic of Estonia passed by a referendum held on 28 June 1992. Pieejams: http://www.legaltext.ee/text/en/X0000K1.htm [aplūkots 10.03.2019.].

${ }^{63}$ The Constitution of the Republic of Lithuania passed by a referendum held on 25 October 1992. Pieejams: http://www.lrkt.lt/Documents2_e.html [aplūkots 10.03.2019.].

${ }^{64}$ Likums “Grozijumi Latvijas Republikas Satversmē”: LV likums. Pieņemts 15.10.1998. Pieejams: http:// www.likumi.lv/doc.php?id=50292 [aplūkots 10.03.2019.].

65 French Constitution held on 4 October 1958. Pieejams: http://www.assemblee-nationale.fr/english/8ab. asp [aplūkots 10.03.2019.].

${ }^{66}$ Latvijas Republikas Satversme. 2017, 4. lpp.
} 
Latvijas Republikas Satversmē”, kas paredzēja mainìt Latvijas Republikas Satversmes 4., 18., 21., 101. un 104. pantu, piešķirot krievu valodai otrās valsts valodas statusu. ${ }^{67}$ Šis referendums apliecināja latviešu valodas kā nāciju apvienojošas konstitucionālas vērtības nozīmi. Referendumā piedalījās nepieredzēti liels pilsoṇu skaits - 70,5\% balsstiesīgo, no kuriem par otrās valsts valodas statusa piešķiršanu krievu valodai nobalsoja $24,9 \%$ vēlētāju, bet pret $-74,8 \%{ }^{68}$ Referenduma rezultāti aktualizēja jautājumu par latviešu valodu kā vienīgo valsts valodu, kas pieder pie Satversmes negrozāmā kodola un veido Latvijas Republikas konstitucionālo identitāti.

Satversmes tiesa jau 2001. gadā uzsvēra: "N̦emot vērā vēsturiskās īpatnības, to, ka latviešu skaitliskais sastāvs 20. gadsimta laikā valsts teritorijā ir samazinājies, atsevišksās lielākajās pilsētās, arī Rīgā, pamatnācija joprojām ir minoritāte un latviešu valoda tikai nesen atguvusi valsts valodas statusu, nepieciešamība aizsargāt valsts valodu un nostiprināt tās lietošanu ir cieši saistīta ar Latvijas valsts demokrātisko iekārtu."69 "[Tāpēc] ievērojot latviešu valodas kā valsts valodas nostiprinājumu Satversmē, kā arī to, ka globalizācijas apstākḷ̆os Latvija ir vienīgā vieta pasaulē, kur var tikt garantēta latviešu valodas un līdz ar to arī pamatnācijas pastāvēšana un attīstība, latviešu valodas kā valsts valodas lietošanas jomas sašaurinājums valsts teritorijā uzskatāms arī par valsts demokrātiskās iekārtas apdraudējumu." 70

Viss iepriekšminētais apliecina Latvijas likumdevēja un konstitucionālās justīcijas pūles, ${ }^{71}$ aizsargājot valodu. Varētu likties, ka Latvijas valsts un nācija ir darījusi visu, lai latviešu valoda kā vērtība būtu juridiski aizsargāta, lai tā varētu pildìt savu kultūrpolitisko misiju, proti, būt galvenā saziṇas valoda Latvijas Republikā visās dzīves sfērās. Taču diemžēl tā nav. Īpaši aktuāls ir jautājums par latviešu valodas lietojumu zinātnē, kas skatāms ciešā kopsakarā ar izglītību, jo pētniecība ir turpinājums izglītībai. ${ }^{72}$ Savukārt izglītība ir atkarīga no pētniecības rezultātiem, tostarp mācību grāmatām, kurās tiek attīstīti jaunākajiem zinātnes atklājumiem atbilstoši jēdzieni latviešu valodā.

Pētot zinātniskās darbības normatīvo regulējumu, iezīmējas latviešu valodas apdraudējums globalizācijas iespaidā. Proti, apdraudējums latviešu valodas lietojumam un lìdz ar to arī valodas attīstībai zinātnē izriet no normatīvā regulējuma, kuru noteikusi tā pati valsts, kas vienlaikus uzsver, ka mūsu nācijas galvenā vērtība ir latviešu valoda. No vienas puses, valsts ir veikusi virkni pasākumu, lai paplašinātu valsts valodas lietojumu izglītībā: ir pieņemts Valsts valodas likums (cik autore izpētījusi, šis ir vienīgais likums, kas gandrīz 20 gadu laikā nav grozīts), ${ }^{73}$ vairākus gadu desmitus cittautieši bez maksas apguvuši latviešu valodu, aktīvi darbojas Valsts valodas centrs un Latviešu valodas aǵentūra, pēctecīgi un

${ }^{67}$ Par grozījumiem Latvijas Republikas Satversmē. 2012. Centrālā vēlēšanu komisija. Pieejams: https:// www.cvk.lv/lv/tautas-nobalsosanas/par-grozijumiem-latvijas-republikas-satversme-2012 [aplūkots 10.03.2019.].

68 2012. gada 18. februāra tautas nobalsošana par likumprojekta "Grozījumi Latvijas Republikas Satversmē” pieņemšanu. Balsotāju aktivitāte. Centrālā vēlēšanu komisija. Pieejams: http://www.tn2012.cvk. lv/activities.html [aplūkots 10.03.2019.].

69 Satversmes tiesas 21.12.2001. spriedums lietā Nr. 2001-04-0103, 3.2. punkts.

70 Ibid.

71 Satversmes tiesā skatīta virkne lietu, kurās analizēta valsts valoda kā konstitucionālās identitātes sastāvdaḷa, piemēram, 21.12.2001. spriedums lietā Nr. 2001-04-0103, 05.06.2003. spriedums lietā Nr. 2003-02-0106, Satversmes tiesas 17.11.2017. lēmums par tiesvedības izbeigšanu lietā Nr. 2017-01-01.

72 Sordet B. Iespējamā Eiropa. Rīga: Mansards, 2014, 37. lpp.

73 Valsts valodas likums: LV likums. Pieņemts 09.12.1999. Pieejams: https://likumi.lv/doc.php?id=14740 [aplūkots 14.03.2019.]. 
apdomīgi lēni tiek reformētas skolu ar krievu apmācības valodu programmas, lai pārietu uz mācībām valsts valodā, likumos ir ierobežojumi augstskolās docēt svešvalodās (Izglītỉbas likuma 9. pants nosaka: "Valsts, pašvaldību un valsts augstskolu izglītības iestādēs izglītību iegūst valsts valodā." $)^{74}$ utt. Valsts mērḳtiecīgi ir darbojusies, lai izglìtības valoda valstī būtu latviešu valoda.

Vai tiešām šo valsts centienu rezultātā latviešu valoda pilnasinīgi nosedz visas dzīves jomas? Ne gluži, un pat ne izglītībā. Globalizētā pasaule diktē savus noteikumus. Latvijas augstskolas tiecas pēc starptautiskiem reitingiem, kurus savukārt var iegūt tikai tad, ja pētnieki publicē savus darbus angḷu valodā tiešsaistes zinātniskos laikrakstos. Zinātne ir kḷuvusi par preci, kas tiek piedāvāta pasaules tirgū. Noiets ir pētijumiem angḷu valodā. Bernards Sordē (Bernard Sordet, dz. 1942) secina, ka "[t]irgos ar stabilu noietu nav jānopūlas ar pētniecību, ko iespējams delokalizēt citās valstīs". ${ }^{75}$ Savukārt pētniecība nacionālās valodās ir luksuss, ko var atlıuties tikai bagātas valstis.

Latvijas zinātnes starptautiskā atpazīstamība pēdējo gadu desmitu laikā tiek mērķtiecīgi sekmēta ar normatīvos aktos ieḳ̦autām prasībām zinātniekiem. Kopš 20. gadsimta pirmās desmitgades valsts stimulē zinātniekus publicēt darbus svešvalodās zinātniskos recenzētos laikrakstos. Lai šos procesus iedzīvinātu, tika izveidots eksperta statuss kā īpaša zinātnieka kvalitātes zìme un Zinātnes padome, kas šo statusu piešķir. ${ }^{76}$ Laika gaitā eksperta statusa nozīme pieauga, cita starpā doktora grāda pieškiršanas procedūrās, bet prasības, lai šo statusu iegūtu, aizvien vairāk ierobežoja Latvijas zinātnieku brīvu izvēli, kur un kādā valodā publicēties. ${ }^{77}$ Zinātnieku brīvības ierobežošana atsaucas arī uz valsts valodas lietojumu izglìtībā, jo mazinās zinātnisko publikāciju skaits latviešu valodā, tostarp mācību grāmatu skaits, kas vitāli nepieciešamas studijām latviešu valodā. Jau tagad daudzās studiju programmās gluži kā padomju laikos latviski ir tikai lekcijas, bet visa studiju literatūra pamatā ir svešvalodās, tikai LPSR literatūra bija krievu valodā, tagad galvenokārt angḷu valodā. Visās zinātṇu nozarēs ienāk aizvien jauni jēdzieni, kas angliski ir saprotami gan pasniedzējam, gan studentam, tāpēc nav nepieciešamības tos tulkot latviski. Tas savukārt noved pie tā, ka latviešu valodas attīstība noteiktās nozarēs nenotiek pietiekami dinamiski vai nenotiek vispār. Publiskajā telpā aizvien biežāk, ekspertiem diskutējot par savu nozari, līdz ar latviešu vārdiem komunikācijā iezogas ang̣̦u valodas jēdzieni. Proti, ir atklāts jauns fenomens, kam globālajā zinātnē jau ir jēdziens, bet latviskā nosaukuma tam nav un, iespējams, arī nebūs. Sekas ir tālejošas: vispirms kavējas latviešu valodas attīstība kādā zinātnes novirzienā, un tas rezultējas stagnācijā izglìtībā latviešu valodā šajā nozarē, bet vēl pēc kāda laika speciālisti nespēs latviski komunicēt par darbu...

Valstij jāapzinās, ka tā ir atbildīga ne tikai par izglìtību valsts valodā, bet arī par zinātni valsts valodā, jo bez zinātnes valsts valodā nav pieejama izglītība valsts valodā.

\footnotetext{
${ }^{74}$ Piemēram, Izglītības likums ar grozijumiem līdz 18.10.2018.: LV likums. Pieṇemts 29.10.1998. Pieejams: https://likumi.lv/doc.php?id=50759 [aplūkots 14.03.2019.].

75 Sordet B. 2014, 37. lpp.

${ }^{76}$ Latvijas Zinātnes padomes nolikums: Ministru kabineta noteikumi Nr. 383. Pieņemti 09.05.2006. Pieejams: https:/likumi.lv/ta/id/135251-latvijas-zinatnes-padomes-nolikums [aplūkots 14.03.2019.].

77 Noteikumi par Latvijas Zinātnes padomes ekspertu kvalifikācijas kritērijiem, ekspertu komisiju izveidošanu un to darbības organizēšanu: Ministru kabineta noteikumi Nr. 724. Pieṇemti 12.12.2017. Pieejams: https://likumi.lv/ta/id/295783-noteikumi-par-latvijas-zinatnes-padomes-ekspertu-kvalifikacijas-kriterijiem-ekspertu-komisiju-izveidosanu-un-to-darbibas-organi [aplūkots 14.03.2019.].
} 


\section{Kopsavilkums}

1. Vērtības ir garīgas un materiālas reālijas, kas ḷauj cilvēkiem apmierināt viṇu vajadzības, vēlmes, intereses un liek atturēties vai, tieši otrādi, piepūlēties, lai tās sasniegtu, iegūtu un saglabātu. Tās vieno sabiedrību, nodrošinot paaudžu pēctecību, sociālo integritāti un sabiedrības ilgtspēju.

2. Postmodernā kultūra, kuru raksturo tiesiska valsts un pamattiesību ievērošana, dod ikvienai personai izvēli brīvi izpausties, abstrahējoties no tradicionālām kolektīvām vērtībām. Pati kultūra ir ne vairs monohroma, bet gan multikulturāla un piedāvā vērtību plurālismu. Tāpēc sabiedrību nacionālā valstī vieno nevis kādas sociālas grupas (etniskas, reliğiskas, interešu u. c. grupas) specifiskas vērtỉbas, bet gan "konstitucionālajā patriotismā" sakṇota konstitucionālā identitāte un to veidojošās konstitucionālās vērtības.

3. Valsts valoda nav nošḳirama no nācijas konstitucionālās identitātes. Valsts valoda - Latvijas Republikā latviešu valoda - ir būtiska konstitucionāla vērtība. Latviešu valodai juridisku statusu un tam atbilstošu aizsardzību ir noteicis likumdevējs, to nostiprinot gan Satversmē, gan arī ārējos normatīvos aktos. Līdz ar likumdevēju latviešu valodu kā konstitucionālu vērtību savas kompetences robežās aizsargā Satversmes tiesa.

4. Valsts valoda visupirms ir konstitūcijas, likumu, pārvaldes un justīcijas valoda. Vienlaikus valsts valoda sekmē sabiedrības integrāciju, jo nodrošina iespēju visiem sabiedrības locekḷiem savstarpēji komunicēt vienā valodā un lìdzdarboties pilsoniskā sabiedrībā. Lai persona varētu pilnvērtīgi līdzdarboties visos sociālajos procesos, valsts pienākums ir veidot izglìtības sistēmu, kurā mācības notiek valsts valodā. Pildot šo pienākumu, valsts gan sekmē pilsoniskās sabiedrības vienotību, gan nodrošina katras personas pamattiesību īstenošanas priekšnoteikumu.

5. Jau kopš Latvijas Republikas dibināšanas likumdevējs ir veidojis izglītības sistēmu latviešu valodā, īpašu uzmanību pievēršot augstākajai izglītībai latviešu valodā, kas savukārt sekmē zinātnes attīstību latviski un nodrošina valsti ar speciālistiem, kuri, pildot amata pienākumus, visos profesionālos jautājumos spēj komunicēt valsts valodā. Arī spēkā esošie normatīvie akti noteic, ka valsts, pašvaldību un valsts augstskolu izglītības iestādēs izglīiību iegūst valsts valodā.

6. Globalizētā pasaule diktē savus noteikumus. Zinātne ir kḷuvusi par preci, kas tiek piedāvāta pasaules tirgū. Noiets ir pētījumiem angḷu valodā. Lai sekmētu Latvijas zinātnes starptautisko atpazīstamību, pēdējo gadu desmitu laikā ar normatīvajos aktos iekḷautām prasībām tiek mērḳtiecīgi sekmēts, lai Latvijas zinātnieki savus pētījumus publicētu atvērtajā piekḷuvē (Open Access), proti, starptautiskos, zinātniskos anonīmi recenzētos tiešsaistes žurnālos angḷ valodā. Šos noteikumus neievērojot, zinātnieks tiek ierobežots savās zinātnieka tiesībās, tostarp strādājot izglītības sistēmā ar doktorantiem.

7. Prasības, kas tiek izvirzìtas zinātniekiem, būtiski ietekmē zinātnisku pētījumu skaitu latviešu valodā. Sarūkot zinātniskiem pētījumiem un mācību grāmatām latviski, studentiem studiju procesā jāizmanto publikācijas svešvalodās. Tādējādi tiek pārkāpta valsts prasība izglītības iestādēm un personas tiesības iegūt augstāko izglītību latviešu valodā. Valstij ir jāapzinās, ka tā ir atbildīga ne tikai par izglītību valsts valodā, bet arī par zinātni valsts valodā. 